\title{
Spin-offs in the Lodging Industry
}

\author{
Linda Canina \\ Cornell University \\ Teri Klein \\ Cornell University
}

\begin{abstract}
Many lodging companies now find themselves in a challenging position. They are finding it more difficult to attract capital as the industry's growth begins to stabilize due to the inherent cycles and the onset of supply growth. Companies seeking growth and access to public financing must confront questions regarding the best structure as the marketplace changes. Many hotel companies are hybrid enterprises, functioning as operating companies and heavy investors in real estate. The two sides of the business have different risk and potential growth profiles. Specialization achieved through spin-offs may lead to higher growth, better access to capital markets, and improvements in shareholder value. Other research has found a positive stock price reaction to the announcement of spin-offs for the overall market. This paper analyzes whether the financial market perceives spin-offs in the lodging industry as creating additional value. These results will assist lodging managers as they make decisions concerning the structure of the firm in an attempt to maximize value.
\end{abstract}

Linda Canina, Ph.D., is an Assistant Professor of Finance and Teri Klein is an MMH candidate in the School of Hotel Administration at Cornell University. 


\section{Introduction}

Many lodging companies now find themselves in a challenging position as the industry's growth begins to stabilize due to the inherent cycles and the onset of supply growth. Public lodging companies are finding it more difficult to support earnings per-share increases at the rates required to continue to attract investors. Companies seeking growth and access to public financing must confront questions regarding the best structure as the marketplace changes. The idea of managing for shareholder value is extremely important in the lodging industry as long as managers continue to look toward Wall Street for financing.

Growth is critical to extending the future horizon for lodging companies in the capital markets. Many hotel companies are hybrid enterprises, functioning as operating companies and heavy investors in real estate. The two sides of the business have different risk and potential growth profiles. Perhaps this hybrid structure is suitable for diversifying owner risk. However, it is not beneficial for investors who hold diversified portfolios. As a result, specialization achieved through restructuring may lead to higher growth, better access to capital markets, and improvements in shareholder value. Since the trend in the lodging industry has been toward specialization and consolidation, this paper analyzes whether specialization in the lodging industry is perceived by the financial market to create additional value.

In 1992, when Marriott Corporation announced its plan to split into two publicly held companies, the idea was described as radical and controversial. ${ }^{1}$ However, the corporate spin-off ${ }^{2}$ as a form of corporate restructuring is not new to U.S. industry. In fact, the first spin-off was undertaken in 1911 by Standard Oil. ${ }^{3}$ Since the beginning of the 1990s this type of divestiture has become better recognized and utilized by the hospitality industry to enhance the value of shareholder investments. From 1992 to 1995 there were five announcements of spin-offs in the lodging industry alone.

\footnotetext{
${ }^{1}$ The Washington Post, "The Unseen Hand Behind Marriott's Split-Up Plan," p. FI, Oct. 12, 1992.

${ }^{2}$ Defined as the distribution of all or substantially all of ownership interest of one firm (the parent) in another firm (the subsidiary) to the parent's shareholders so that following the spin-off there are two publicly held companies.

${ }^{3}$ Kudla, Ronald and Thomas Mclnish. Corporate Spin-Offs, Quorum Books, Westport, Connecticut, p. $101,1984$.
} 
Spin-offs are a form of corporate restructuring in which the parent firm becomes smaller. A spinoff creates a separate new legal entity; its shares are distributed on a pro rata basis to existing shareholders of the parent company. Thus, existing shareholders have the same proportion of ownership in the new entity as in the original firm. There is, however, a separation of control, and over time, the new entity as a separate decision making unit may develop policies and strategies different from those of the original firm. Note that no cash is received by the original parent. The original holdings simply are divided into two or more parts.

Spin-offs are the mirror image of mergers and yet the two are alleged to increase aggregate market value. In the case of mergers, synergies may be one possible factor behind the increase in value. It is less obvious with spin-offs why the aggregate market value of the shares of the two units trading separately should exceed the market value as a single unit. Even though a spin-off does not alter the composition of assets supporting the shareholders' claims, a spin-off does alter contracts among stockholders, creditors, managers, and regulators. Therefore, the changes in existing and future contracts are potential sources of gain attributed to the spin-off. In certain cases the expected gains from two separate, specialized sets of contracts, each tailored to the specific units, exceed the expected costs of the spin-off and provide the impetus for the divestiture. Just as mergers might provide for economies of scale in contracting among similar operations, spin-offs might eliminate diseconomies of scale among dissimilar operating units.

As the giants of the lodging industry such as Marriott, Promus, ITT, and Hilton have expanded to include businesses as varied as gaming, real estate ownership, lodging operations, and management services, the conclusion has been reached that expansive diversification not only detracts from managerial focus, but also clouds information that is conveyed to investors and may ultimately act to decrease shareholder value. The reduction of the size and diversity of the asset base under a given management may improve managers' productivity and increase their efforts to direct resources effectively. The separation of lines of business by a spin-off may improve the efficiency of total asset management. 
This paper investigates the effects of corporate spin-off announcements on shareholder wealth in the lodging industry. We find that spin-offs in the lodging industry have created additional wealth for shareholders. A significant positive average share price reaction is documented for seven voluntary spinoff announcements between 1964 and 1995 in the lodging industry. The creation of value from these spinoffs may be the result of spin-off -induced organizational changes and/or corporate control activity. Organizational changes associated with spin-offs may induce superior parent and spin-off operating performance as a result of a reduction in agency and overhead costs, a sharpened focus, market allocation as opposed to administrative capital allocation, and/or incentives created by more effective compensation of management. In addition, these spin-offs may have created value by facilitating the transfer of the assets of either the parent or the subsidiary to more highly valued uses.

The rest of the paper is organized as follows. In the next section, we describe various forms of corporate restructuring, such as sell-offs and spin-offs. In Section 3, we present the underlying reasons for spin-offs. In Section 4, we describe our sample, methodology, and results, respectively. We conclude with a brief summary.

\section{Corporate Restructuring}

Corporate restructuring can take several different forms: divestitures, equity carve-outs, spin-offs, split-offs, and split-ups. A divestiture is a sale of a portion of the firm to an outside party. The selling firm is usually paid in cash, marketable securities, or a combination of the two. An equity carve-out is a variation of a divestiture that involves the sale of an equity interest in a subsidiary to outsiders. The sale may not necessarily leave the parent company in control of the subsidiary. The new equity gives the investors shares of ownership in the portion of the selling company that is being divested. In an equity carve-out, a new legal entity is created with a stockholder base that may be different from that of the parent selling company. The divested company has a different management team and is run as a separate firm. 
A new legal entity is also created in a spin-off. As with an equity carve-out, new shares are issued, but they are distributed to stockholders on a pro rata basis. As a result of the proportional distribution of shares, the stockholder base in the new company is the same as that of the old company. Although the stockholders are the same, the spun-off firm has its own management and is run as a separate company. Another difference is that a spin-off normally does not provide the parent with a cash infusion, whereas a divestiture involves an infusion of funds into the parent corporation.

In a split-off, some of the stockholders in the parent company are given shares in a division of the parent company, which is split off in exchange for their shares in the parent company. Lastly in a split-up, the entire firm is broken up into a series of spin-offs. The end result of a split-up is that the parent company no longer exists; only the newly formed companies remain. The stockholders in the companies may be different, since stockholders exchange their shares in the parent company for shares in one or more of the units that are spun off.

\section{Why Spin Off?}

If there are no synergies between the parent and the spun-off subsidiary, the sum of the postdivestiture cash flows equals what would have been the combined cash flows of the parent and the subsidiary had the two remained as one. In the absence of synergy and in a frictionless capital market, the spin-off would not be expected to affect valuation. However, in reality, valuation is affected by a spin-off due to the associated costs and benefits. The spin-off requires registration of the new share certificates, distribution of the new shares, and duplication of the servicing costs associated with dividend payments, ownership transfers, listing on a organized exchange, and so on. As the spun-off firms expand, they lose the advantage of economies of scale in raising external capital. Further, if there is any positive synergy to joint operation, it will be lost in the spin-off. The benefits of independent operations must exceed these costs if stockholders' interests are to be sewed through a spin-off.

A spin-off is not the only way to separate the operations of the two units. Another way of achieving independence would be to create an autonomous subsidiary, with the parent supplying the capital and the subsidiary passing its income from operations to the parent. This would eliminate any 
diseconomies of scale or operational inefficiencies without incurring the duplication of the servicing costs mentioned previously. If a spinoff is a more costly transaction than the creation of an autonomous subsidiary, then benefits must be identified that cannot be achieved with the independent sub-unit, in order to rationalize a spin-off.

It has been suggested that gains arise from the effect on the set of contracts, both existing and future, constituting the firm. The redeployment of assets and change of control associated with a spin-off affect the existing contracts, especially the senior securities such as bonds and preferred stock. Divestitures are motivated by a variety of factors. The need for a spin-off may arise because a division of the company is performing poorly or simply because it no longer fits into the finds plans. Restructuring may also be necessary to undo a previous merger or acquisition that proved unsuccessful. For some companies, divestitures are among the few alternatives available to help pay down debt. In most cases, divestitures occur for one or more of the following reasons.

\section{Poor Fit of Division}

Companies sometimes refer to a business as being a "poor fit." By spinning it off, the management of the parent company can concentrate on its main activity. If each business must stand on its own feet, there is no risk that funds will be siphoned off from one in order to support unprofitable investments in the other. Moreover, if the two parts of the business are independent, it is easy to see the value of each and to reward managers accordingly.

A divestiture may create value by slicing off a business that was a poor fit with the remaining operations. If so, good divestiture programs may increase the market values of both companies. In addition, there may be improvements in managerial accountability and a strengthening of incentives may be achieved by separating unrelated business activities.

As a result of these improvements, divestitures may provide managers with greater decisionmaking authority. Better performance evaluation may also be achieved. For example, the parent company may want to move out of a particular line of business that it feels no longer fits into its plans or in which it is unable to operate profitably. This does not mean that another firm, with greater expertise in this line of 
business, could not profitably manage the division's assets. Divestitures then become part of an efficient market process that reallocates assets to those who will allow them to reach the greatest gain.

\section{Poor Performance}

Companies may want to divest divisions simply because they are not sufficiently profitable. The division could fail to pay a rate of return that exceeds the parent company's hurdle rate-the minimum return threshold that a company will use to evaluate projects or the performance of parts of the overall company.

\section{Capital Market Factors}

A divestiture may also take place because the parent firm, as well as the divested division, has greater access to capital markets. The combined corporate structure may be more difficult for investors to categorize. Divestitures might provide greater access to capital markets for the two firms as separate companies than as a combined corporation.

Many companies spin off segments because they feel that investors do not properly value the parent firm due to the diverse types of operations it encompasses. In many situations, the parent firm and the spin-off firm have operated in very different lines of business and different market atmospheres. Each division has distinct operating, financial, and investment characteristics (reflected in the volatility of their earnings), resulting in the two entities having different levels of risk. The spinning off of subsidiaries allows the resulting companies to attract capital on a basis consistent with their unique marketplaces. The abilities of the parent firm and the spin-off firm to raise capital become directly related to the relevant capital markets affecting their respective businesses. Firms are also able to issue debt for future expansion through terms that are more in line with their unique historical and projected growth rates. under these circumstances, the spin-off serves to insulate each of the businesses from the risks associated with the other. Costs of capital and debt are realigned according to the respective risks of the individual companies. 
A potential disadvantage to a spin-off in this case, however, is that financing may actually be more difficult to obtain after a separation because each company is no longer able to rely on the earnings, cash flows, and assets of the other. The bond ratings for the more risky firm could be lowered.

\section{Intensified Management Leadership and Focus}

The spinning-off of a corporate division or subsidiary creates separate, publicly traded companies which have their own dedicated, specialized management staff and board of directors. Management teams no longer have to divide their focus, expertise, and business resources between the different operations that exist under one corporate umbrella. Decisions can be based upon the specific frameworks within which the newly segregated businesses operate. In addition, because the operational and financial progress of each business is more visible to stockholders, the separation provides a stimulus to executives to show growth and improvement. A clearer basis for evaluation of performance is provided for the public and to the investment community.

\section{Taxes}

Tax benefits can be obtained through spin-offs in at least three ways. If the principal asset of a company is real estate, it may be able to qualify as a real estate investment trust (REIT). Unlike other corporations whose dividends are payable only after payment of corporate income taxes, corporations that qualify as REI'Is may deduct dividends paid to shareholders from income before calculating their taxes.

In addition, a firm may transfer income-producing properties to a trust and distribute interest in the trust to its stockholders, thereby avoiding payment of corporate income taxes on the income from the property. Lastly, if a United States-based company derives significant revenues from overseas, it may be advisable to incorporate its foreign operations outside the United States and then spin off the resulting firm. The revenues of the spin-off firm would then be taxed at the tax rates that prevail in the country of incorporation, which may be lower than in the United States.

\section{Marketing Considerations}

Corporations may enact spin-offs due to marketing considerations. Some spin-offs have been designed to allay fears of customers, suppliers, and others that the parent firms were not committed to, 
and might end participation in, particular industries. Spinoffs may also be implemented to separate potentially incompatible product lines.

\section{Regulatory and Legal Issues}

Regulatory and legal factors have also been the cause of both voluntary and involuntary spin-offs. Spin-offs can be planned to separate regulated and unregulated businesses or designed to circumvent legal obstacles that prevent a firm from accomplishing its objectives.

\section{Spin-offs in the Lodging Industry}

The most common reason for creating spin-offs is that they improve efficiency. This is consistent with the explanations given by lodging managers. Management focus and capital market factors are the most frequently cited explanations given by lodging managers for spin-offs. An example of capital market misevaluation motivating a firm to divide operations is the Promus Corporation's decision to spin off its gaming division under the name Harrah's Entertainment. The company's decision to spin off was due largely to the fact that the company's stock price did not accurately reflect the value of the company's hotel division because the casino business, perceived as very risky, overshadowed other operations. When ITI' announced its plan to spin off its businesses to create three separate, publicly owned corporations in July 1995, the CEO said the decision was made for two fundamental reasons: specialization and access to capital markets. It was expected that the new structure would allow the management of the companies to focus more intensively on their respective businesses and provide the flexibility for each company to grow in a manner best suited for its industry with an expected increase in the availability and decrease in the cost of raising capital. In addition, they claimed that the separation would enable the management of each of these businesses to organize their capital structure and design corporate policies and strategies that would be based primarily on the business characteristics of the company and to concentrate its financial resources wholly on its own operations. 


\section{Data, Methodology, and Empirical Results}

\section{Data}

We examine the effects of pure spin-off announcements on shareholder wealth by studying a sample of six lodging companies that announced seven spin-offs over the 1964-1995 period. These companies were identified using the stock distributions coded as spin-offs (3763) on the CRSP Daily Master File of the American Stock Exchange, the New York Stock Exchange, and NASDAQ firms and from the Wall Street Journal Index. We excluded all cases in which the announcement date or stock prices could not be found in the WalI Street Journal Index, The Wall Street Journal, the Nexus database, the Bloomberg database, or the CRSP tapes. We define a pure spin-off as a tax-free, pro rata distribution of shares of a wholly owned subsidiary to shareholders. All distributions of other firms' stock are considered by U.S. tax authorities to be dividends. Fully taxable spin-offs, which represent the most frequent type of distribution, tend to involve either a parent firm retaining a large percentage of the common shares of a spin-off subsidiary or a firm distributing to its own shareholders a large block of shares of another publicly traded firm. For a distribution to be tax-exempt under the criteria set forth in Internal Revenue Code Section 355, it must represent at least $80 \%$ of the outstanding shares of the subsidiary, and any shares retained by the parent must not constitute "practical control" of the subsidiary. As such nontaxable spin-offs represent restructuring in which a parent firm effectively removes itself from the management and ownership of the subsidiary. These pure spin-offs represent the restructuring studied here. ${ }^{4}$ Table 1 presents the yearly distribution of the seven spin-off announcements.

Daily closing prices of the stock for each company were obtained from the CRSP Daily File. The sample period, for each company is defined as 102 days before the announcement date through one day

\footnotetext{
${ }^{4}$ To be nontaxable, a spin-off must be motivated by business considerations, not tax avoidance. Furthermore, Section 355 of the Tax Code requires that parent and subsidiary be actively engaged in business for at least five years before the spin-off, that the parent own at least 80 percent of the subsidiary's stock, that the parent distribute all of its subsidiary securities, and that no prearranged plan exists for shareholders to sell the subsidiary stock subsequent to the distribution. Failure to satisfy these conditions implies tax treatment of spin-off shares as dividend income to the parent firm shareholders.
} 
after the announcement date. The daily returns were computed as the log price relatives adjusted for dividends.

\section{Methodology}

The effect of voluntary spin-offs on shareholder wealth is examined by testing the statistical significance of the unexpected return of the stock during the event period for the portfolio of announced spin-offs in the hospitality industry using the event study methodology. ${ }^{5}$ The mean model is used to estimate the expected return during the estimation period. The event period is defined as one day before through one day after the announcement date. The estimation period consists of 100 trading days prior to the event period.

A brief description of the standard event study methodology used to compute the excess returns and t-statistics during the announcement period follows. First, the expected return was computed during the estimation period by event $I$, by company $j$ :

$$
\overline{R_{j i}}=\frac{\sum_{t=-101}^{-2} R_{j i t}}{N_{j t}}
$$

Where:

$t \quad$ is the $t^{\text {th }}$ day relative to a given announcement date $I$ for firm $j$

$R_{\text {jit }} \quad$ is the $\log$ price relative for firm $j$, event $I$, day $t$,

$N_{j i} \quad$ the number of trading days in the estimation period for event $I$, company $j$.

The unexpected or excess return is calculated for each day t in the event period, by event $I$, by company $j$. It is defined as the actual daily return minus the expected return.

$$
e^{\wedge}{ }_{j i t}=R_{j i t}-\bar{R}_{j i}
$$

\footnotetext{
${ }^{5}$ See Brown and Warner $[1980,1985]$ for a detailed explanation of event study methodology.
} 
where $t$ denotes the $t^{\text {th }}$ day relative to a given announcement date $I$ for firm $j$. The excess returns are averaged across events and companies to compute the unexpected return for the entire portfolio of spinoffs for each day $t$ in the event period. ${ }^{6}$

$$
\overline{e_{t}}=\frac{\sum_{j=1}^{6} \sum_{i=1}^{I_{j}} e_{j i t}^{\wedge}}{\sum_{j=1}^{6} I_{j}}
$$

where $I_{j}$ represents the number of announcements of dividend increases for company $j$.

In order to test the statistical significance of the daily excess returns by event and the daily excess returns for the spin-off portfolio, t-statistics were calculated, in the following manner:

1) Calculate the $t$-statistic for the unexpected return, by event day $t$, by announcement $I$ :

$$
t\left(e^{\wedge}{ }_{j i t}\right)=\frac{e^{\wedge}{ }_{j i t}}{s e^{\wedge}}
$$

2) Calculate the t-statistic for the unexpected return on the portfolio of announced spin-offs, by event day $t$ :

$$
\overline{t\left(e_{t}\right)}=\frac{\sum_{j=1}^{6} \sum_{i=1}^{I_{j}} t\left(e^{\wedge}{ }_{j i t}\right)}{\sqrt{\sum_{j=1}^{6} I_{j}}}
$$

where $s e_{i}$ is the standard error of the unexpected returns calculated over the 100-day estimation period prior to the event period of each announcement.

\footnotetext{
${ }^{6}$ All statistics are computed assuming independence.
} 


\section{Results}

The unexpected return for each day in the event period, by announcement, and the unexpected return for each day in the event period for the portfolio of spin-offs are shown in Table 2. Notice that for all but one of the announcements, there is a positive price response from the market on the announcement date and/ or the previous date. The exception is Hilton, where there is a significantly negative stock price response on the announcement date. However, this announcement is unique because there were two announcements from Hilton on that date. In addition to the spin-off, there was news that the company was unable to find a buyer for their hotel and gambling operations. The market believed that Hilton's decision to spin off its casinos to shareholders was the result of their failure to find a buyer.

The average unexpected returns for the portfolio of spin-offs for the day preceding (day -1 ) and the day of the announcement (day 0) are 3.09\% and 2.16\%, respectively. Significance tests of the unexpected returns are also given in Table 2. The average excess returns on days -1 and 0 have t-statistics of 4.3 and 2.2, respectively, which indicate statistically significant (at the 0.01 level) share price reactions on each of the two days. On average, the market views spin-offs as a means to create additional value. The significant shareholder gains from voluntary spin-offs reported in Table 2 are not surprising if managers maximize shareholder wealth.

In order to gain further understanding of these results, the background of the company, the objective of the spin-off, and the stock market's reaction to the announcement of the spin-off is analyzed in the cases of Marriott Corporation, Promus Companies, Hilton Hotels, and ITT Corporation.

\section{Marriott Corporation}

On October 5, 1992, Marriott Corporation (NYSE:MAR) announced a plan to divide its operation into two separate, publicly traded companies: Host Marriott (NYSE:HMf), which would replace the original Marriott Company and focus solely on real estate ownership- oriented activities, and Marriott International (NYSE:MAR), which would control all of Marriott's lodging management and services operations. On October 4, the plan was approved by Marriott's Board of Directors and on October 8, 
1993, the company was officially divided through a special dividend distribution of one share in the newly formed Marriott International for each share of the original Marriott Corporation.

\section{Objectives}

1. Increased Profit and Growth Potential

Prior to the spin-off, Marriott's operations included both ownership and management of hotels and service outlets. Marriott's services business was comprised of its hotel, motel, and cafeteria management operations. This segment generated cash and profits with little risk and only a small amount of investment required. In its services division, Marriott was able to receive $3 \%$ of a hotel's gross revenue and a percentage of its profit. Even in recessionary times, Marriott's lodging management business could continue to grow if the company could expand the number of properties under its management. In contrast, the hotel development and ownership side of Marriott's operations were capital intensive with high associated debt levels resulting from real estate investments. Marriott was able to realize little of the profit potential of its services division due to the high interest charges associated with its ownership segment.

2. Increased Access to Capital

In addition, the impact of the debt associated with its massive real estate holdings caused Marriott to have only limited access to capital at reasonable rates for the purpose of expanding its more profitable management services business. ${ }^{7}$ Thus, it was believed that after the spin-off, Host Marriott would be able to focus upon managing its real estate holdings for long-term cash flow without the pressure of having to sell off assets during depressed times to sustain a healthy financial position for the company as a whole.

3. Reduction of Asymmetric Information

Marriott's management also believed that the combination of the company's real estate ownership operations and its management services businesses caused confusion and

\footnotetext{
${ }^{7}$ Marriott Corporation, Notice of1993 Annual Meeting and Proxy Statement, p. 19, June 19,1993.
} 
misperception by investors, resulting in misevaluation of the company as a whole. ${ }^{8}$ Marriott officials used the example that during recessionary times the company's real estate property would depreciate in value, causing book earnings to fall, and ultimately having a negative effect on Marriott's share price. Marriott believed, however, that real estate holdings should be measured not on the basis of book earnings but rather on the basis of cash flow or other financial measures.

Marriott executives (under the leadership of CFO Steve Bollenbach) came to the decision to split the company and to create Marriott International as a growth-oriented company. It would include the company's 734 hotel and motel management contracts, its 3,000 corporate and institutional cafeteriamanagement agreements, and management of its retirement communities, all with virtually no debt. ${ }^{9}$

Host Marriott would replace the original Marriott Corporation and would exist as a smaller real estate holding company and would assume almost all of the parent company's debt. Host Marriott would also control several cash generating assets such as food and beverage and merchandise concessions at airports and on toll-roads. ${ }^{10}$ In addition, Host Marriott was to be given access to a $\$ 600$ million line of credit guaranteed by Marriott International. The announcement of the planned spin-off was officially made on October 5, 1992.

\section{Market Reaction}

Upon announcement of the split, Marriott stock closed with a unexpected gain of $12.3 \%$. This abnormal return is statistically different from zero at the $1 \%$ significance level. It has been hypothesized that this excess return represents a wealth transfer from bondholders to stockholders. Marriott's bondholders filed a class action suit when the value of the debentures decreased by $30 \%$ upon announcement that all debt would be assumed by Host Marriott. This decrease in value resulted from

\footnotetext{
${ }^{8}$ Announcement to Shareholders, Marriott Corporation International Headquarters, June 19, 1993.

${ }^{9}$ The Washington Post, "The Unseen Hand Behind Marriott's Split-Up Plan," p. FI, Oct. 12, 1992.

${ }^{10}$ Reuters Limited, "Marriott Sees Host with Healthy Cash Flow," Oct. 22, 1992.
} 
Moody's Investors Services downgrading Marriott's \$1.4 billion in senior-level debt from Baa3 to Ba2

Gunk status) and lowering their ratings on \$400 million of other Marriott debt and preferred stock.

Moody's stated that "prior to the announcement, Moody's grade rating was based on expectations that the company would continue to pay down debt as it had indicated it intended to do in recent financial documents ..." $" 11$

\section{Promus Companies}

On January 30, 1995, the Promus Companies Incorporated (NYSE:PRI) announced a planned spin-off that would divide the company into two independent public corporations: Promus Hotels (NYSE:PRH) for conducting its hotel business, and Harrah's Entertainment (NYSE:HET) for conducting its casino entertainment business. The spin-off, which resulted in the creation of the largest stand-alone gaming corporation in North America, ${ }^{12}$ was officially completed on June 30, 1995.

Prior to the spin-off, the Promus Companies Incorporated had operated two large divisions: lodging and gaming operations. Harrah's represented Promus's casino brand, while the company's hotel division included Embassy Suites, Hampton Inn, and Homewood Suites. Prior to Promus's decision to divide, its stock had fallen as "investors soured on the gaming industry after its growth slowed in 1994."13 The company had also suffered from ongoing political controversy surrounding its New Orleans landbased casino. ${ }^{14}$ By January 26 of 1995 (four days before the announcement of the spin-off), Promus stock was trading at $\$ 31.88$, down from a 52-week high of $\$ 55.25 .^{15}$

\footnotetext{
${ }^{11}$ Bondholders protested that Marriott had originally issued its debt on the basis that it would be backed by all of the assets of the company. Shortly after the announcement, a "steering committee" of major bondholders hired a Wall Street law firm to develop a lawsuit against Marriott and to assist in any settlement negotiations. Marriott withstood months of legal battles and negotiations with various bondholder groups, ending with a settlement to bondholders and the completion of the spin-off. Despite the settlement terms, Moody's and Standard \& Poor's stated that Host Marriott would be speculative-grade.

${ }^{12}$ Promus Companies News Release, "Promus Announces Plan to Split Company", February 6, 1995.

${ }^{13}$ Casino Journal's National Gaming Summary, "Promus Splits Hotel, Gaining Entities," pp. 1-2, Feb. 6, 1995.

${ }^{14}$ Ibid.

${ }^{15}$ Ibid.
} 


\section{Objectives}

1. Reduction of Agency Costs through Management Restructuring

The Board of Directors at Promus held the belief that the casino and hotel divisions of PRI had separate growth strategies that needed to be refined according to their unique market positions. They believed that each area needed the specialized attention of a "dedicated" corporate management team. In addition, the Chairman of Promus, Michael D. Rose, stated that:

by separating the companies, we will be able to more accurately focus accountability and rewards. The managers of each business will become more directly accountable to their stockholders and incentive programs tied to the share price of each company should help ensure a strong correlation between management performance and shareholder value creation. ${ }^{16}$

\section{Growth Opportunities}

Promus leaders believed that although the sharing of technology, systems, and policies had at one time provided a synergistic foundation for the company's hotel and gaming divisions, the sharing of resources had become a constraint in the growth of the two entities. Each of the segments was viewed as needing strategic refinement with a singular focus on its own individual objectives and growth needs. After the spin-off, each business would be free to grow at its own rate with no internal competition for time, resources, or capital. Promus viewed the split as allowing their hotel segment to take advantage of the "surging lodging industry" by creating its own visibility in the market to create enhanced growth opportunities. Likewise, the spin-off would allow the casino company to continue to bid on operations in new gaming jurisdictions. ${ }^{17}$

\section{Capital Market Perception \& Valuation}

The Promus team believed that the Promus stock price did not accurately reflect the value of the company's hotels. Because the casino business was perceived as risky, it overshadowed the

\footnotetext{
${ }^{16}$ Promus Companies Incorporated News Release, "Promus Announces Plan to Split Company," p. 2, Feb. 6, 1995.
}

${ }^{17}$ Casino Journal's National Gaming Summary, "Promus Splits Hotel, Gaming Entities," p.1, Feb. 6,1995. 
profitability of the lodging division. By separating Promus into two companies, it was hoped that analysts, investors, and lenders would be better able to recognize and act upon the strengths of the individual businesses, particularly the hotel business whose individual strengths and prospects had been overlooked by the market. ${ }^{18}$ Duff and Phelps analyst Joyce Minor stated that "the split would unlock the value of the hotels ... a big benefit to shareholders." 19

\section{Market Reaction}

Analysts reacted positively to the news of the Promus divestiture. Jason Ader, Vic President and gaming analyst for Smith Barney, said the hotel stock should trade at a premium compared to other issues in the field. Bruce Turner, analyst for Salomon Brothers said, "the deal will prove that the sum of Promus' parts separated is greater than the whole."20

Investors also responded strongly to the announcement of the Promus split, driving prices up by $5.2 \%$ on the day the announcement was made, generating a positive abnormal return of $5.3 \%$. The excess return of $5.3 \%$ is significantly different from zero at the $5 \%$ significance level.

\section{Hilton Hotels}

On May 11 of 1995, Hilton Hotels announced a planned spin-off that would create two separate, publicly traded companies: one controlling Hilton's gaming division and one for conducting the company's hotel businesses. Although the spin-off was contingent upon certain regulatory and other thirdparty approvals, Hilton scheduled the completed spin-off to take place in early $1996 .{ }^{21}$

\section{Objectives}

Hilton's board initiated the spin-off idea based upon the belief that the company's divisions would be able to develop and operate more effectively as separate companies. In addition, many investors and

\footnotetext{
18 Promus Companies News Release, "Promus Announces Plan to Split Company," Feb. 6, 1995.

${ }^{19}$ St. Louis Post Dispatch, "Gaming Firm to Split off Hotel Business," Jan. 31, 1995.

${ }^{20}$ Casino Journal's National Gaming Summary, "Promus Splits Hotel, Gaming Entities," pp. 1-2. Feb. 6.1995.

${ }^{21}$ Ronson, Charles, "Spin Off Report/Bloomberg Business News," June 2, 1995.
} 
analysts felt that the spin-off would help facilitate a sale of Hilton (a possibility that the company had been examining). American Express Financial Advisors expressed that the spin-off would possibly attract more potential buyers because of the desire to purchase either Hilton's casino business or the hotel operations rather than the whole company. ${ }^{22}$ For example, potential buyers seeking only hotel assets would not have to deal with the gaming business and the regulatory requirements such as obtaining casino licenses. $^{23}$

\section{Market Reaction}

Hilton's shares had risen from about \$58 in early November 1994 due to improved earnings and the anticipation of a sale. ${ }^{24}$ Upon announcement of the spin-off, however, Hilton stock prices fell by 8.6\%, as investors viewed it as being a statement that the company would not, after all, sell. As shown in Table 2, news of the proposed spin-off generated abnormal negative returns of $-8.5 \%$. Chairman and CEO Barron Hilton remarked that the market might have concluded that this was the only option Hilton had decided to take. He stated that was not the case, and that all of Hilton's options (including a sale) were still open. ${ }^{25}$ This announcement is unique because there were two announcements from Hilton on that date. In addition to the spin-off, there was news that the company was unable to find a buyer for their hotel and gambling operations. The market believed that Hilton's decision to spin off its casinos to shareholders was the result of its failure to find a buyer.

\section{ITT}

On June 13, 1995, ITT Corporation's (NYSE:ITT) Board of Directors approved a management plan to divide ITT into three separate, publicly traded corporations: ITT Hartford for conducting insurance services, ITT Industries Inc. for the manufacturing of industrial products, and the new ITT Corporation which would control ITT' s hospitality, entertainment, and information services division.

\footnotetext{
${ }^{22}$ Bloomberg Business News, "Hilton to Spin-Off Casino Operations; Shares Fall," p. 1, May 11, 1995.

${ }^{23}$ Klein, David, Princeton Newsroom/Bloomberg Data Base, May 11, 1995.

${ }^{24}$ Bloomberg Business News, "Hilton to Spin-Off Casino Operations; Shares Fall," p. 4, May 11, 1995.

${ }^{25}$ Idem, p. 2.
} 
Upon completion, the transaction (involving sales and revenues of \$25 billion) will be one of the largest of its kind in business history. ${ }^{26}$

\section{Objectives}

The Chief Executive Officer of ITT, Rand Araskog, stated that the creation of three companies was a "natural business progression" and that the three businesses would be best positioned as independent, publicly owned companies. The following objectives were sought by ITT leaders through the spin-off.

1. Management Restructuring

ITT' s CEO stated that one objective of the spin-off was to allow management to focus more intensively on their own businesses in order to provide each company the flexibility to grow in a manner best suited for its industry.

2. Capital Market Perception \& Valuation

ITT' s management had long felt that Wall Street undervalued its businesses because of the complexity of its conglomerate activity. ${ }^{27}$ Araskog stated that as a result of the spin-off, investors would be better able to evaluate the financial performance of each company, as well as its businesses and strategies, resulting in an increased access to the capital markets at a lower cost of capital. $^{28}$

\section{Market Reaction}

Analyst Jay Cohen of Salomon Brothers viewed the transaction as "a very good move." He said that investors would appreciate the chance to value the companies independently, and added that previous spin-off deals had served to "reenergize" management. Other investors agreed, driving the ITT share price up by more than 5 dollars. ${ }^{29}$ This positive reaction was reflected in returns generated on the day of the

\footnotetext{
${ }^{26}$ PR Newswire Association, PR Newswire, June 13,1995.

${ }^{27}$ Reuters, Limited, "Financial Report: ITT to Spin-Off Three Public," June 13, 1995.

${ }^{28}$ PR Newswire Association, Inc., PR Newswire, Financial News Section. June 13, 1995.

${ }^{29}$ The Financial limes Limited: Investors Chronicle, "US Break-Up-ITT Does the Splits," June 16,1995.
} 
ITT spin-off announcement, and was responsible for the positive abnormal return of $4.9 \%$ realized by ITT.

\section{Conclusions}

During the 1970s, spin-offs were aggressively utilized by manufacturing conglomerates. Even though there were a few spin-offs in the hospitality industry during the 1960s and 1980s, it has only been since the beginning of the 1990s that this type of divestiture has become better recognized and utilized by the hospitality industry to enhance the value of shareholder investments. On average, the stock market perceived the overall value of the separate and distinct lines of business to be greater than the market value of the whole pie. The unexpected daily returns on the portfolio of announced spin-offs were $3 \%$ and $2 \%$ on the day preceding and the day of the spin-off announcement, respectively. The unexpected return for the sample of lodging firms is slightly greater than that found using a sample representative of the overall market. For the overall market, Hite and Owers (1983) found the excess returns to be about 2.3\% and $1.0 \%$ on the day preceding and the day of the spin-off announcement, respectively.

Many companies in the lodging industry spin off segments because they feel that investors do not properly value the parent firm due to the diverse types of operations it encompasses. In many situations, the parent firm and the spin-off firm have operated in very different lines of business and different market atmospheres. Each division has distinct operating, financial, and investment characteristics (reflected in the volatility of their earnings), resulting in the two entities having different levels of risk. The spinning off of subsidiaries allows the resulting companies to attract capital on a basis consistent with their unique marketplaces. The empirical evidence presented in this paper is consistent with managers maximizing the value of the firm. This paper shows that specialization in the lodging industry is perceived by the financial market to create additional value. In each case, the parent company spun off a division with different operating, financial, and investment characteristics. For example, Marriott split its property company, Host Marriott, away from its hotel management arm, Marriott International; ITT Corporation completed a spin-off of Sheraton Hotels into a separate company; and Promus Company spun out its gaming 
operations as a separate entity from its hotel operations. As a result, lodging companies seeking growth and access to public financing should consider restructuring as a means of increasing shareholder value. 


\section{References}

Brown, S., \& Warner, J. (1980). Measuring security price performance. Journal of Financial Economics, 8, 205-258.

Brown, S., \& Warner, J. (1985). Using daily stock returns: The case of event studies. Journal of Financial Economics, 14, 3--31.

Cusatis, P.J., Miles, J.A., \& Woolridge, J.R. (1993, June). Restructuring through spin-offs, the $\quad$ stock market evidence. Journal of Financial Economics, 293--311.

Hite, G., \& Owers, J. (1983, December). Security price reactions around corporate spin-off announcements. Journal of Financial Economics, 409-436.

Jensen, M.C. (1993, July). Presidential address: The modern industrial revolution, exit, and the failure of internal control systems. Journal of Finance, 831-880.

Kudla, R., \& Mclnish, T. (1984). Corporate Spin-Offs. Westport, Conn.: Quorum Books.

Miles, J., \& Rosenfeld, J. (1983). An empirical analysis of the effects of spin-off announcements on shareholder wealth. Journal of Finance, 38, 1597-1606.

Mitchell, M.L., \& Mulherin, J.H. (1996). The impact of industry shocks on takeover and restructuring activity. Journal of Financial Economics, 41, 193-229.

Parrino, R. (1997). Spinoffs and wealth transfers: The Marriott case. Journal of Financial Economics, 43, 241-274.

Schipper, K, \& Smith, A. (1983, December). Effects of recontracting shareholder wealth: The case of voluntary spin-offs. Journal of Financial Economics, 437-467. 
Table 1. Yearly Distribution of Spin-Offs in the Lodging Industry, 1964-1995.

\begin{tabular}{|c|c|c|c|}
\hline Year & Company & Announcement Date & $\begin{array}{c}\text { Date Spin-Off } \\
\text { Occurred }\end{array}$ \\
\hline 1964 & Hilton Inc. & October 16, 1964 & December 2, 1964 \\
\hline 1989 & Holiday Corp. & August 24, 1989 & February 8, 1990 \\
\hline 1992 & Marriott Corp. & October 5, 1992 & October 8, 1993 \\
\hline 1995 & Promus Companies & January 30, 1995 & June 30, 1995 \\
\hline 1995 & Hilton Hotel & May 11, 1995 & Spin-off canceled \\
\hline 1995 & ITT Corp. & June 13, 1995 & December 15, 1995 \\
\hline 1995 & Host Marriott & August 9, 1995 & December 29, 1995 \\
\hline
\end{tabular}


Table 2. Unexpected Returns during the Announcement Period, for Each Spin-Off Announcement and for the Portfolio of Spin-Off Announcements

\begin{tabular}{|c|c|c|c|c|}
\hline \multirow[b]{2}{*}{ Company } & \multirow[b]{2}{*}{$\begin{array}{c}\text { Announcement } \\
\text { Date } \\
\end{array}$} & \multicolumn{3}{|c|}{$\begin{array}{l}\text { Unexpected Return on Event Day Relative to } \\
\text { Announcement Date }\end{array}$} \\
\hline & & Day -1 & Day 0 & Day 1 \\
\hline Hilton Inc. & October 16, 1964 & $\begin{array}{c}0.500 \\
(0.201)\end{array}$ & $\begin{array}{c}4.000 \\
(1.695)\end{array}$ & $\begin{array}{l}-0.600 \\
(-0.266)\end{array}$ \\
\hline Holiday Corp. & August 24, 1989 & $\begin{array}{l}10.500 \\
(3.921)\end{array}$ & $\begin{array}{c}6.900 \\
(2.580)\end{array}$ & $\begin{array}{l}-2.700 \\
(-0.995)\end{array}$ \\
\hline Marriott Corp. & October 5, 1992 & $\begin{array}{c}12.3 \\
(8.022)\end{array}$ & $\begin{array}{c}-0.700 \\
(-0.477)\end{array}$ & $\begin{array}{l}-0.100 \\
(0.055)\end{array}$ \\
\hline Promus Cos. & January 30, 1995 & $\begin{array}{l}-1.900 \\
(-0.733)\end{array}$ & $\begin{array}{c}5.300 \\
(2.107)\end{array}$ & $\begin{array}{c}3.500 \\
(1.397)\end{array}$ \\
\hline Hilton Hotels & May 11, 1995 & $\begin{array}{l}-0.800 \\
(-0.518)\end{array}$ & $\begin{array}{l}-8.500 \\
(-5.706)\end{array}$ & $\begin{array}{l}-2.600 \\
(-1.739)\end{array}$ \\
\hline ITT Corp. & June 13, 1995 & $\begin{array}{c}0.000 \\
(0.007)\end{array}$ & $\begin{array}{c}4.900 \\
(4.132)\end{array}$ & $\begin{array}{c}2.000 \\
(1.639)\end{array}$ \\
\hline Host Marriott & August 9, 1995 & $\begin{array}{c}1.000 \\
(0.517)\end{array}$ & $\begin{array}{c}3.200 \\
(1.596)\end{array}$ & $\begin{array}{l}-2.200 \\
(-1.082)\end{array}$ \\
\hline Portfolio & & $\begin{array}{c}3.090 \\
(4.308)\end{array}$ & $\begin{array}{c}2.160 \\
(2.213)\end{array}$ & $\begin{array}{l}-0.390 \\
(-0.416)\end{array}$ \\
\hline
\end{tabular}

